\title{
Upaya Orang Tua Menumbuhkan Minat Baca Anak pada Alkitab
}

\section{Parents' Efforts to Foster Children's Reading Interest in the Bible}

\author{
Libertina Hulu1, Delipiter Lase ${ }^{2}$, Amurisi Ndraha ${ }^{3}$ \\ ${ }^{1}$ Program Studi S1 PAK STT Banua Niha Keriso Protestan Sundermann \\ ${ }_{23}$ STT Banua Niha Keriso Protestan Sudermann Nias \\ libertinahulu2@gmail.com
}

\section{ARTICLE INFO}

Submitted: July 16, 2021

Review: July 19, 2021

Accepted: August 24, 2021

Published: August 26, 2021

\section{KEYWORDS}

children and the Bible, foster children's interest in reading the Bible, parents' efforts

\section{CORRESPONDENCE}

Phone:

E-mail: piterlase@sttsundermann.ac.id

\begin{abstract}
A B S T R A C T
Creative teaching the Bible to children from an early age will help them understand the main things about life, strengthen them to face and overcome challenges and teach children to live a life that is not dominated by sin. Therefore, parents are obliged to cultivate children's interest in reading the Bible early because parents are the first closest people to children. This article investigates how children are interested in reading the Bible and finding out the causal factors. At the end of the discussion, the author describes the efforts and strategies of parents to foster children's interest in reading the Bible. The research was developed using qualitative methods. Participants numbered fourteen parents and children aged 6-12 years; determined by purposive sampling techniques. The data is netted through observations and interviews, and the data obtained is analyzed with thematic analysis. The findings suggest that children's reading interest in the Bible is still exceptionally low; every ten primary-school-age children have no more than three people who like (have an interest) in reading the Bible. The causes of children's low interest in reading the Bible are classified into four factors: the family environment, reading facilities and facilities, technological developments, literacy, and parenting. At the end of the article, the author suggests some efforts that parents can apply to foster children's interest in reading the Bible, including providing a variety of Bible reading materials, arranging worship times in the family, limiting children's activities to watch and play excessively, and make meditation time as a habit.
\end{abstract}

\section{A B S TRAK}

Mengajarkan Alkitab secara kreatif kepada anak-anak sejak usia dini akan menolong mereka untuk memahami hal yang utama tentang kehidupan, menguatkan mereka menghadapi dan mengatasi tantangan serta mengajari anak untuk menjalani kehidupan yang tidak didominasi oleh dosa. Karena itu, orang tua berkewajiban untuk menumbuhkan minat baca anak terhadap Alkitab sejak dini, karena orang tua adalah orang yang terdekat pertama bagi anak. Artikel ini bertujuan untuk menyelidiki bagaimana minat baca anak terhadap Alkitab, mencari tahu faktor penyebab serta pada bagian akhir pembahasan, penulis memaparkan upaya dan strategi orang tua menumbuhkan minat baca anak terhadap Alkitab. Penelitian dikembangkan dengan menggunakan metode kualitatif. Sumber data dan informan berjumlah 14 orang terdiri dari orang tua dan anak usia 6-12 tahun; ditentukan dengan teknik purposive sampling. Data diambil berdasarkan observasi dan wawancara, serta data yang telah diperoleh dianalisis dengan teknik 
analisis tematik. Temuan penelitian menujukkan bahwa minat baca anak terhadap Alkitab masih sangat rendah; setiap sepuluh orang anak usia sekolah dasar terdapat tidak lebih dari tiga orang yang gemar (memiliki minat) membaca Alkitab. Penyebab rendahnya minat baca anak terhadap Alkitab diklasifikasi ke dalam empat faktor, yakni lingkungan keluarga, sarana dan fasilitas bacaan, perkembangan teknologi, literasi baca tulis dan pola asuh orang tua. Pada bagian akhir artikel, penulis menyarankan beberapa upaya yang dapat diterapkan oleh orang tua untuk menumbuhkan minat baca anak terhadap Alkitab, di antaranya menyediakan bahan bacaan Alkitab yang beragam, mengatur waktu ibadah dalam keluarga, membatasi kegiatan anak untuk menonton dan bermain secara berlebihan, serta menjadikan waktu renungan sebagai kebiasaan.

Kata kunci: anak dan Alkitab, menumbuhkan, minat baca Alkitab, upaya orang tua

\section{PENDAHULUAN}

S ebagai orang Kristen, perlu membaca Alkitab, karena Alkitab merupakan katakata Allah yang ditujukan kepada manusia. ${ }^{1}$ Membaca Alkitab secara teratur dan konsisten memiliki beberapa manfaat. Pertama, Alkitab menunjukkan kepada manusia karakter Allah dan memberikan manusia wahyu Allah tentang diri-Nya kepada umat-Nya. Di setiap bagian Alkitab, tampak karakter Allah yang kudus, tidak berubah, setia, pengasih dan pengasih. Kedua, 2 Timotius 3:16-17 ketika membahas topik Kitab Suci mengatakan bahwa itu "bermanfaat untuk mengajar, untuk teguran, untuk koreksi dan untuk pelatihan dalam kebenaran." Ayat berikutnya melanjutkan - dengan mengatakan bahwa ini mengarah pada kelengkapan dan perlengkapan "untuk setiap pekerjaan yang baik". Ketiga, membaca firman Tuhan secara teratur akan mengubah arah pemikiran manusia sehingga dapat bertumbuh dalam kedewasaan, yang merupakan bagian dari panggilan Kristen (Efesus 4:14-16; Roma 12:1-2).

Pemikiran penulis di atas sejalan dengan pernyataan Koehler yang menjelaskan tentang membaca Alkitab bagi orang Kristen memiliki empat manfaat, yakni pertama mengajar kebenaran tentang Allah dan karya-Nya, kedua menyatakan kesalahan pengajaran yang tidak sesuai dengan kebenaran. Ketiga memperbaiki kelakuan yang salah dan keempat ialah mendidik orang dalam kebenaran (2 Tim 3:1617). ${ }^{2}$

1 Anwar Tjen, trans., Katekhismus Dr. Martin Luther, 5th ed. (Jakarta: BPK Gunung Mulia, 2007), 33.

2 Edward Koehler, Intisari Ajaran Kristen (Pematangsiantar: Kolportase Pusat, 2010), 19.
Alkitab memiliki kedudukan yang sentral dalam kehidupan agama orang Kristen. ${ }^{3}$ Itulah sebabnya Alkitab perlu diajarkan sejak dini. Mengajarkan Alkitab secara kreatif kepada anakanak dapat memberi manfaat; yakni pertama, mengajarkan mereka tentang masalah kehidupan yang penting. Mazmur 119:24 "Ya, peringatan-peringatan-Mu menjadi kegemaranku, menjadi penasihat-penasihatku." Adalah penting untuk mengajari anak tentang masalah kehidupan penting yang mungkin mereka hadapi dan bagaimana mereka dapat mengatasinya. Cerita-cerita Alkitab menampilkan pergumulan yang berbeda yang dihadapi oleh individu yang berbeda dan bagaimana mereka dapat mengatasinya. Kisahkisah ini dapat menjadi pelajaran hidup penting yang dapat dibawa oleh anak-anak setiap saat.

Kedua, menguatkan anak-anak (Yesaya 43:13). Alkitab mengajar anak-anak tumbuh menjadi individu yang kuat yang siap menghadapi dan mengatasi tantangan apa pun yang diberikan kehidupan kepada mereka saat ini atau di masa depan. Ketiga, memberi mereka bimbingan (Amsal 6:23). Anak-anak kecil yang mudah dipengaruhi membutuhkan bimbingan, dan salah satu cara untuk mengajari mereka pelajaran hidup yang penting adalah melalui cerita-cerita Alkitab. Perintah, pengajaran, dan kata-kata dalam Alkitab dapat menjadi pedoman penting yang dapat membantu menjaga mereka agar tidak tersesat. Keempat, mengajari anak untuk menjalani kehidupan yang tidak didominasi oleh dosa. Mazmur 119:11 "Dalam hatiku aku

3 Marlianti Datu, "Meningkatkan Minat Anak Sekolah Minggu Untuk Membaca Alkitab Di Era Globalisasi" (OSF Preprints, 2020), https://osf.io/rfky9/. 
menyimpan janji-Mu, supaya aku jangan berdosa terhadap Engkau."

Manfaat membaca Alkitab bagi anak-anak juga dijelaskan oleh Wijayani, yakni "anak-anak dapat membangun kerohanian (spiritualitas) melalui kehidupan tokoh di dalam Alkitab, dan belajar mengenai prinsip-prinsip iman mereka. Anak-anak yang rajin membaca Alkitab akan mengenal lingkungan dan hal-hal yang terjadi di dunia sekitarnya; mereka dapat menemukan cara untuk menangani masalah yang dihadapi, serta membantu anak mengembangkan perilaku sadar untuk bertumbuh secara rohani." 4

Memperkenalkan anak-anak kepada Yesus dan melihat mereka tumbuh dalam hubungan mereka dengan Allah merupakan tanggung jawab orang tua Kristen. Orang tua memiliki tanggung jawab mendorong anak untuk membaca Alkitab secara teratur. "Didiklah orang muda menurut jalan yang patut baginya, maka pada masa tuanyapun ia tidak akan menyimpang dari jalan itu" (Amsal 22:6).

Secara etimologis, anak diartikan sebagai manusia yang masih kecil atau manusia yang belum dewasa. ${ }^{5}$ Seseorang yang belum berusia 18 (delapan belas) tahun, termasuk anak yang masih dalam kandungan. ${ }^{6}$ Merupakan harta yang paling berharga bagi orang tua di dalam keluarga, yang tidak pernah bisa dibeli dan digantikan dengan benda apapun. Kehadiran anak di tengah keluarga berdampak pada keberlangsungan keluarga tersebut karena anak yang akan meneruskan kehidupan keluarga dimasa yang akan datang. ${ }^{7}$ Demikian juga di dalam gereja, anak adalah masa depan tumbuh kembanganya sebuah gereja. Karena anak merupakan anugerah yang diberikan Allah kepada setiap orang tua yang sudah dipersatukan Allah (Mazmur 127:3), 8 maka anak wajib untuk dididik, diajar, dan juga dibesarkan di dalam keluarga supaya menjadi generasi

4 Elisabeth Lita Wijayani, "Efektivitas Penggunaan Cerita Bergambar Sebagai Media Pengenalan Tokoh Kitab Suci Pada Siswa Kelas II Sekolah Dasar Soegijapranata Klaten Utara" (Universitas Sanata Darma, 2017), 2.

${ }^{5}$ W. J. S. Poerwadarminto, Kamus Umum Bahasa Indonesia (Jakarta: Balai Pustaka, 1984).

6 Undang-Undang Nomor 23 Tahun 2002 Tentang Perlidungan Anak (Jakarta: Sekretariat Negara Republik Indonesia, 2002), 4. penerus dalam keluarga dimasa yang akan datang.

Sejak dini, anak diajari untuk takut akan Tuhan, membimbing mereka dengan lemah lembut dan penuh kasih sayang. Anak-anak juga perlu dididik agar mereka memiliki empati terhadap orang lain. Sejak dini anak-anak diperkenalkan dengan firman Tuhan sehingga benih-benih Injil dapat berakar dan bertumbuh dalam hati anak-anak (2 Timotius 1:5-6). ${ }^{9}$ Masa anak di usia dini ini benar-benar merupakan masa yang tepat untuk meletakkan fondasi bagi pembentukan kepribadian secara utuh sehingga mereka memiliki kesiapan dalam memasuki pendidikan lebih lanjut. ${ }^{10}$

Akan tetapi realita berbicara lain, temuan awal penulis menunjukkan adanya situasi atau keadaan di mana anak-anak yang idealnya telah diajar dan dibiasakan untuk membaca Alkitab oleh orang tua atau keluarga, masih sebatas harapan. Orang tua (sebagian besar) sangat sibuk dengan pekerjaan dan rutinitas lainnya, sehingga tidak memiliki waktu untuk menumbuhkan minat dan membiasakan anak-anak membaca Alkitab. Situasi ini semakin diperburuk oleh rutinitas ibadah keluarga yang dilakukan di rumah, hanya sebatas nyanyi dan berdoa tanpa pembacaan nats Alktiab; aktivitas pelayanan Sekolah Minggu di wilayah pinggiran kota (suburban) dan pelosok (rural) tidak terlaksana dengan baik bahkan tidak ada, serta kemampuan baca tulis anak yang pada dasarnya rendah. Ini menunjukkan anak-anak tidak memiliki waktu atau kesempatan yang cukup untuk membaca Alkitab dan karena pendampingan orang tua, anakpun pada akhirnya boleh memahami setiap firman Tuhan yang dibacanya.

Keluarga merupakan lingkungan pertama bagi anak-anak untuk memeroleh pendidikan dan pengajaran. Sebagai lingkungan awal, keluarga merupakan agen terdepan dalam pembentukan watak atau kepribadian anak-

7 Philip J. King and Lawrance E. Stager, Kehidupan Orang Israel Alkitabiah (Jakarta: BPK Gunung Mulia, 2012).

${ }^{8}$ Elisabeth, Pembelajaran PAK (Pendidikan Agama Kristen) Bagi Anak Usia Dini (Bandung: Bina Media Informasi, 2009), 1.

${ }^{9}$ Ibid., 14.

${ }^{10}$ Ibid., 2. 
anak. ${ }^{11}$ Ada banyak nilai yang ditanamkan oleh keluarga terhadap anak-anak; keluarga membentuk konsep diri (self-worth) anak, mengajarkan cara berkomunikasi, menanamkan disiplin, mendidik anak untuk dapat memainkan peranan sosial. ${ }^{1213}$ Keluarga adalah "gereja kecil" yang Tuhan pakai sebagai "sekolah" untuk anakanak, sekaligus agen Allah untuk mewarnai dunia sekitar. ${ }^{14}$

Orang tua memiliki tanggung jawab yang besar terhadap keberlangsungan pendidikan anak. Ulangan 6:7 menjelaskan tentang perintah kepada orang tua untuk mengajarkan anak secara berulang-ulang; mendidik anak menurut jalan yang patut baginya sehingga pada masa dewasa tidak akan berpaling dari kebaikan (Amsal 22:6). Orang tua berkewajiban dan bertanggungjawab untuk mengasuh, memelihara, mendidik, dan melindungi anak; menumbuh-kembangkan anak sesuai dengan kemampuan, bakat, dan minatnya; serta mencegah terjadinya perkawinan pada usia anak. ${ }^{15}$ Orang tua wajib memberikan pendidikan karakter dan penanaman nilai budi pekerti pada anak. ${ }^{16}$ Pendidikan itu sendiri, dimaknai sebagai upaya sadar dan sengaja untuk memperlengkapi seseorang atau sekelompok orang, guna membimbingnya keluar dari satu tahapan ketahapan yang lebih baik. ${ }^{17}$ Merupakan upaya untuk memajukan budi pekerti, pikiran serta jasmani anak agar dapat memajukan kesempurnaan hidup. ${ }^{18}$

Manfaat membaca Alkitab bagi anak-anak orang Kristen dan anak-anak sebagaimana diuraikan di atas, sangat jelas. Karena itu, orang

11 B. S. Sidjabat, Membangun Pribadi Unggul (Yogyakarta: Andi Offset, 2011), 23.

12 Ibid., 24.

13 Asmat Purba, “Tanggung Jawab Orang Tua Kristen Dalam Mendidikan Anak Menyikapi Pandemi Covid-19," EPIGRAPHE: Jurnal Teologi dan Pelayanan Kristiani 4, no. 1 (May 29, 2020), http://jurnal.stttorsina.ac.id/index.php/epigraphe/ article/view/151.

14 Hasanema Wau, Gereja Pasca Covid-19 (Yogyakarta: Andi Offset, 2020), 46.

15 Undang-Undang Republik Indonesia Nomor 35 Tahun 2014 Tentang Perlindungan Anak (Sekretariat Negara Republik Indonesia, 2014).

16 Undang-Undang Republik Indonesia Nomor 20 Tahun 2003 Tentang Sistem Pendidikan Nasional (Sekretariat Negara Republik Indonesia, 2003). tua berkewajiban untuk menumbuhkan minat baca anak terhadap Alkitab sejak dini, karena orang tua adalah orang yang terdekat pertama bagi anak. Pendidikan dimulai dari rumah dan seharusnya orang tua berperan maksimal dalam menumbuhkan minat membaca karena membaca adalah awal dari proses pendidikan, dari membaca anak-anak dapat mengetahui segala hal, memacu daya nalar dan konsentrasi anak. ${ }^{19}$

Richards mengatakan bahwa fokus pengajaran Alkitab bukan hanya sekedar memberikan informasi saja, akan tetapi hendaknya menolong anak untuk menghubungkan pengetahuan tentang isi Alkitab dan implikasinya. ${ }^{20}$ Dengan bimbingan yang benar dari orang tua, mereka dapat membedakan antara yang benar dengan yang salah dan memiliki nurani yang lembut; dapat mengambil keputusan menerima Tuhan Yesus Kristus dan mempersembahkan diri mereka untuk melayani Tuhan Yesus. ${ }^{21}$

Minat baca merupakan suatu keinginan atau kecendrungan yang tinggi (gairah) untuk membaca. Seseorang yang mempunyai minat membaca yang kuat akan diwujudkan dalam kesediaannya untuk mendapat bahan bacaan dan kemudian membacanya atas kesadarannya sendiri.22 Wahadaniah dalam Ratnasari (2011) menjelaskan bahwa minat baca merupakan perhatian yang kuat dan mendalam disertai dengan perasaan senang terhadap kegiatan membaca sehingga dapat mengarahkan seseorang untuk membaca dengan kemauannya sendiri atau dorongan dari luar. ${ }^{23}$ Melalui

17 B. Samuel Sidjabat, Strategi Pendidikan Kristen Suatu Tinjauan Teologis-Filosofis (Yogyakarta: Andi Offset, 1994), 8.

18 Thomas H. Groome, Christian Religious Education (Jakarta: BPK Gunung Mulia, 2010), 8.

19 Darmadi, MEMBACA, YUUUK.....! "Strategi Menumbuhkan Minat Baca Pada Anak Sejak Usia Dini" (Yogyakarta: Guepedia Publisher, 2018), 213.

20 Lawrence O. Richards, Mengajarkan Alkitab Secara Kreatif (Bandung: Yayasan Kalam Hidup, 1994), 138.

21 Paulus Lilik Kristianto, Prinsip Dan Praktik PAK (Yogyakarta: ANDI, 2006), 87-93.

22 Farida Rahim, Pengajaran Membaca Di Sekolah Dasar (Jakarta: Bumi Aksara, 2008), 28.

23 Yunita Ratnasari, "Pengaruh Pergaulan Teman Sebaya Terhadap Teman Sebaya Terhadap Minat Baca Siswa Kelas V SD Negeri Bojongsari I 
aktivitas membaca, seseorang memperoleh pengetahuan yang luas dan dapat memahami bahasa yang tertulis. Rasa ingin tahu sesuatu dalam bentuk bacaan yang diminati setiap individu akan mendapat jawaban atas pertanyaan. Agar minat baca anak boleh tumbuh dan berkembang, memerlukan bimbingan dari orang lain, seperti orang tua dan guru di sekolah.

Beberapa teori atau temuan penelitian sebelumnya mengindikasi bahwa "anak-anak harus diajarkan untuk membaca Alkitab berulang-ulang dan merenungkannya. Stanislius mengatakan bahwa sejak usia anak-anak Yahudi 5 tahun mereka sudah diajarkan untuk mempelajari Kitab Suci, usia 10 tahun mempelajari Mishnah, usia 13 tahun mempelajari perintah-perintah dan usia 15 tahun mempelajari Talmud sebagaimana arahan dari perintah Tuhan di dalam Ulangan 6 yang biasa disebut sebagai "Shema Israel". 2425

Pembelajaran Kitab Taurat mendapat tempat yang utama bagi orang tua Yahudi yang diteruskan kepada anak-anaknya secara terus menerus. Menurut Magdalena (2011) sebagaimana dikutip oleh Nainupu \& Emiyati tujuan utama pendidikan anak-anak Yahudi adalah agar mereka bertumbuh dalam Firman Tuhan dan menyembah Tuhan dengan takut dan gentar. Orang tua Kristen dewasa ini juga harus mendorong anak-anak mereka untuk belajar Alkitab sejak usia dini. Perintah yang jelas diberikan kepada orang tua dalam Alkitab adalah mendidik anak untuk takut akan Tuhan, melanjutkan perintah dalam Ulangan 6, untuk terus mengajarkan hukum Tuhan. ${ }^{26}$ Terus menerus atau berulang-ulang di sini berarti tidak terhingga banyaknya bagi orang tua untuk melakukannya. ${ }^{27}$

\footnotetext{
Kabupaten Purbalingga" (Universitas Negeri Yogyakarta, 2011), 16.

24 Surip Stanislaus, Bimbing Anak Cinta Alkitab (Yogyakarta: Kanisius, 2010).

25 Astrid Maryam Yvonny Nainupu and Ayang Emiyati, "Kunci Keberhasilan Seorang Anak Dalam Pemaparan Alkitab," Didache: Journal of Christian Education 1, no. 2 (December 31, 2020): 99, https://journal.sttsimpson.ac.id/index.php/DJCE/a rticle/view/329.

${ }^{26}$ Ibid., 100.

27 Purim Marbun, "Menggagas Pendidikan Karakter," Edukasi: Jurnal Pendidikan Agama Kristen 10, no. 1 (2019): 1-11,
}

Lebih lanjut Darmawan menjelaskan bahwa "mengajarkannya berulang-ulang identik dengan mengasah, dan merupakan suatu proses yang berlangsung terus menerus. Hal yang sama juga yang oleh Tuhan menjadi perintah untuk diperhatikan dan dilakukan oleh Yosua yaitu supaya Yosua memperkatakan Taurat Tuhan dan merenungkannya siang dan malam." 28

Sejak usia dini anak-anak sudah harus diajarkan untuk mengenal firman Tuhan. Suwardi (2007) dalam Nainupu \& Emiyati (2020), mengatakan bahwa "perilaku gemar membaca hendaknya ditumbuhkan sejak dini pada anak agar anak merasa tertarik dan memiliki minat yang tinggi terhadap membaca karena penanaman budaya baca akan lebih sulit diterapkan jika anak telah dewasa". ${ }^{29}$ Anak-anak yang telah belajar Firman Tuhan sejak kecil akan memiliki minat yang kuat dalam membaca Firman Tuhan dan tumbuh dalam rasa percaya diri. ${ }^{30}$ Mulai dari orang tua, mereka membacakan untuk anak-anaknya berulang-ulang. Anak-anak belajar firman dengan mengamati contoh orang tua yang juga mempelajari firman. Keteladanan orang tua membaca dan merenungkan Firman Tuhan menjadi contoh yang baik, dan tentunya anak-anak akan lebih mudah mengikuti. ${ }^{31}$

Bertolak dari uraian di atas, rumusan masalah yang hendak diselidiki melalui penelitian ini adalah (1) bagaimana minat baca anak terhadap Alkitab; (2) apa penyebab rendahnya minat baca anak terhadap Alkitab; dan (3) bagaimana upaya atau strategi orang tua dalam menumbuhkan minat baca anak terhadap Alkitab. Berdasarkan rumusan tersebut di atas, penelitian ini bertujuan untuk menyelidiki sejauh mana minat baca anak pada Alkitab, menjelaskan faktor-faktor penyebab rendahnya minat baca anak pada Alkitab serta memaparkan

http://sttbi.ac.id/journal/index.php/edukasi/article /view/58.

28 I Putu Ayub Darmawan, "Pembelajaran Memorisasi Dalam Ulangan 6:6-9," EPIGRAPHE: Jurnal Teologi dan Pelayanan Kristiani 3, no. 1 (June 17, 2019):

21 , http://www.stttorsina.ac.id/jurnal/index.php/epigr aphe/article/view/50.

${ }^{29}$ Nainupu and Emiyati, "Kunci Keberhasilan Seorang Anak Dalam Pemaparan Alkitab," 100.

30 Datu, "Meningkatkan Minat Anak Sekolah Minggu Untuk Membaca Alkitab Di Era Globalisasi." ${ }^{31}$ Ibid. 
upaya atau strategi orang tua dalam menumbuhkan minat baca anak pada Alkitab masing-masing pada setting penelitian yang dituju.

\section{METODE}

Penelitian ini menggunakan metode penelitian kualitatif, yakni penelitian yang bermaksud untuk memahami fenomena tentang apa yang dialami oleh subjek penelitian. ${ }^{32}$ Pertimbangan untuk memilih metode ini adalah peneliti hendak menyelami kedalaman kompleksitas dan proses; serta variabel terkait belum teridentifikasi. ${ }^{33}$ Sumber data dan informan (partisipan) berjumlah 14 orang, terdiri dari 9 orang orang tua ditambah 5 orang anak (Tabel 1), ditetapkan dengan menggunakan teknik purpose sampling, yakni didasarkan atas kompetensi dan bukan atas dasar keterwakilan. ${ }^{34}$ Data dijaring dengan menggunakan teknik wawancara semi terstruktur ${ }^{35}$ dan observasi. ${ }^{36}$ Analisis data dilakukan dengan menggunakan thematic analysis, merupakan salah satu cara menganalisa data dengan tujuan untuk mengidentifikasi pola atau untuk menemukan tema melalui data yang telah terkumpul. ${ }^{3738}$

\section{HASIL DAN PEMBAHASAN}

\section{Minat Baca Anak Terhadap Alkitab}

Berdasarkan hasil observasi dan wawancara, ditemukan bahwa minat baca anak terhadap Alkitab masih sangat rendah. Dari 5 orang responden (Anak Usia 6-12 Tahun), hanya ada satu orang yang rajin membaca Alkitab [ $\left.R_{14}\right]$, sementara anak-anak yang lain sangat jarang atau jarang (sekali - dua kali dalam seminggu). Mereka membaca Alkitab hanya pada saat belajar agama Kristen di sekolah; dan di rumah -

${ }^{32}$ Lexy J. Moleong, Metodologi Penelitian Kualitatif (Bandung: Remaja Rosdakarya, 2017).

33 Catherine Marshall and Gretchen B. Rossman, Designing Qualitative Research, 6th ed. (Thousand Oaks, CA: SAGE Publications, Inc., 2015).

$34 \mathrm{H}$ Russell Bernard and Bernard H. Russell, Research Methods in Anthropology: Qualitative and Quantitative Approaches (Walnut Creek: AltaMira Press, 2006).

35 Ibid.

36 Brigitte Smit and Anthony J. Onwuegbuzie, "Observations in Qualitative Inquiry: When What You See Is Not What You See," International Journal of Qualitative Methods 17, no. 1 (December 1, 2018): bila guru pendidikan agama Kristen dari sekolah memberi penugasan. Situasi ini tidak hanya terjadi pada kelima keluarga responden di atas, tetapi juga pada keluarga (responden) lainnya. "Anak-anak sangat jarang membaca Alkitab di rumah, dan kesempatan mereka mendengar firman Tuhan selain di sekolah, hanya pada hari minggu ketika hadir di Sekolah Minggu." [R6]

Tabel 1

Subjek (Partisipan/Responden) Penelitian

\begin{tabular}{ccll}
\hline Responden & L/P & Pekerjaan & \multicolumn{1}{c}{ Alamat } \\
\hline $\mathrm{R}_{1}$ & $\mathrm{P}$ & PNS & Desa Boyo \\
\hline $\mathrm{R}_{2}$ & $\mathrm{P}$ & Wiraswasta & Jl. Fondrako No. 4 \\
\hline $\mathrm{R}_{3}$ & $\mathrm{P}$ & Wiraswasta & Jl. Sudirman 130 \\
\hline $\mathrm{R}_{4}$ & $\mathrm{P}$ & PNS & Jl. Fondrako No. 9b \\
\hline $\mathrm{R}_{5}$ & $\mathrm{P}$ & PNS & Jl. Fondrako No. 2 \\
\hline $\mathrm{R}_{6}$ & $\mathrm{P}$ & Wiraswasta & Jl. C. Mangukusumo No.59 \\
\hline $\mathrm{R}_{7}$ & $\mathrm{P}$ & PNS & Desa Hilina'a \\
\hline $\mathrm{R}_{8}$ & $\mathrm{P}$ & PNS & Jl. Dolok Martimbang \\
\hline $\mathrm{R}_{9}$ & $\mathrm{P}$ & PNS & Jl. Fondrako No. 12 \\
\hline $\mathrm{R}_{10}$ & $\mathrm{P}$ & Pelajar & Desa Boyo \\
\hline $\mathrm{R}_{11}$ & $\mathrm{~L}$ & Pelajar & Jl. Cipto Mangukusumo \\
\hline $\mathrm{R}_{12}$ & $\mathrm{P}$ & Pelajar & Desa Hilina'a \\
\hline $\mathrm{R}_{13}$ & $\mathrm{~L}$ & Pelajar & Jl. Dolok Martimbang \\
\hline $\mathrm{R}_{14}$ & $\mathrm{P}$ & Pelajar & Jl. Fondrako No.12 \\
\hline & & &
\end{tabular}

Anak-anak sangat jarang membaca Alkitab dan mendengar firman Tuhan pada kesempatan ibadah keluarga di rumah, karena ibadah keluarga (seperti nyanyi dan doa pada pagi dan malam hari) tidak dilaksanakan secara bersamasama di mana seluruh anggota keluarga hadir untuk bersyukur dan memuji Tuhan $\left[R_{5}\right]$. Selain bahwa, ibadah keluarga dilaksanakan relatif singkat, juga tanpa aktivitas pembacaan dan diskusi firman Tuhan [ $\left.R_{9}\right]$. Pada kesempatan ibadah keluarga ini, anak-anak tidak mendapatkan momen untuk terbiasa membaca Alkitab.

Rendahnya minat baca anak terhadap Alktab di atas, juga akui oleh orang tua. Enam (6)

160940691881676,

http://journals.sagepub.com/doi/10.1177/16094069 18816766.

37 Heriyanto Heriyanto, "Thematic Analysis Sebagai Metode Menganalisa Data Untuk Penelitian Kualitatif," Anuva 2, no. 3 (November 22, 2018): 317, https://ejournal2.undip.ac.id/index.php/anuva/arti cle/view/3679.

38 Virginia Braun and Victoria Clarke, "Using Thematic Analysis in Psychology," Qualitative Research in Psychology 3, no. 2 (January 2006): 77-101, http://www.tandfonline.com/doi/abs/10.1191/147 8088706qp063oa. 
dari 9 (sembilan) responden (orang tua) yang diwawancarai, mengaku bahwa "anak-anak sangat jarang membaca Alkitab, di rumah anakanak lebih banyak menghabiskan waktu untuk menonton dan bermain" $\left[\mathrm{R}_{1}\right]$. "Mereka membaca Alkitab hanya ketika menyelesaikan PR agama dari sekolah; selebihnya anak-anak menggunakan kesempatan belajarnya untuk membaca materi pelajaran lain $\left[\mathrm{R}_{8}\right]$ dan bacaan kontemporer anak-anak seperti buku cerita, komik atau cerita bergambar $\left[\mathrm{R}_{10}\right]$.

Meskipun orang tua kurang memberi perhatian terhadap pentingnya menumbuhkan minat dan membiasakan anak membaca Alkitab sejak dini, namun mereka sangat memahami bahwa Alkitab penting untuk dibaca dan dipahami oleh orang Kristen mulai dari anakanak

\section{Faktor Penyebab Rendahnya Minat Baca Anak Terhadap Alkitab}

Faktor penyebab rendahnya minat baca anak terhadap Alkitab berdasarkan observasi dan wawancara dengan orang tua dan anak usia (6-12 tahun) diperoleh informasi yang cukup beragam. Pertama, anak-anak mengaku belum terbiasa (dibiasakan) untuk membaca Alkitab dalam lingkungan keluarga; lebih tertarik dan menyukai bacaan seperti buku pelajaran (nonAkitab), buku cerita, komik atau cerita bergambar $\left[\mathrm{R}_{10}\right]$. Kedua, orang tua sangat sibuk, akibatnya mereka tidak memiliki waktu untuk mendampingi aktivitas belajar anak di rumah termasuk dalam hal membaca bahan bacaan secara umum dan Alkitab pada khususnya $\left[R_{6}\right.$, $\mathrm{R}_{8}$ ]. Ketiga, mayoritas keluarga melaksanakan ibadah di rumah dalam kesempatan yang relatif singkat (nyanyi dan berdoa) tanpa aktivitas pembacaan Alktab $\left[R_{1}\right]$.

Keempat, rendahnya keteladanan termasuk pola asuh yang ditunjukkan orang tua; ini menyangkut orang tua sebagai sumber inspirasi, tokoh panutan, motivator dan kedisiplinan. Meskipun anak-anak sulit menjelaskan aspek ini, namun hasil penyelidikan, peneliti menemukan realitas tentang berbagai kekurangan dalam pola

39 Delipiter Lase, Amurisi Ndraha, and Gustav Gabriel Harefa, "Persepsi Orang tua Siswa Sekolah Dasar Di Kota Gunungsitoli Terhadap Kebijakan Pembelajaran Jarak Jauh Pada Masa Pandemi Covid19," SUNDERMANN: Jurnal Ilmiah Teologi, Pendidikan, asuh orang tua terhadap anak. Kelima, rendahnya literasi baca tulis anak, khususnya di wilayah pinggiran kota dan pedalaman; menyebabkan anak menghindari bacaan-bacaan yang sifatnya full text, dan diperburuk oleh rendahnya akses ke sumber-sumber bacaan digital. Keenam, keasadaran dan kemampuan orang tua menjadi guru bagi anak-anak di lingkungan keluarga. ${ }^{39}$ Ketujuh, faktor eksternal yang lebih luas mencakup peran gereja dalam konteks gereja yang ramah anak dan orientasi pelayanan yang masih mengedepankan pelayanan bagi orang dewasa dan orang muda.

Temuan penelitian di atas menunjukkan bahwa minat baca anak terhadap Alkitab masih sangat rendah. Hanya ada satu dari lima orang anak usia SD (6-12 tahun) yang gemar membaca Alkitab, selebihnya tidak/kurang tertarik, tidak memiliki keinginan/kecenderungan atau gairah (=minat) untuk membaca Alkitab. Data ini mempunyai nilai (ukuran, arti atau harga) yang sama (ekuivalen) dengan rasio 3:10, artinya setiap sepuluh orang anak usia SD terdapat tidak lebih dari tiga orang yang gemar (memiliki minat) membaca Alkitab.

Meskipun temuan penelitian di atas belum dapat disandingkan dengan temuan penelitian sebelumnya, apakah dalam bentuk skor, rasio atau indeks (sejauh penelusuran, penulis belum menemukan adanya data berupa angka yang relevan). Namun data ini memiliki hubungan yang linear dengan hasil survei Program for International Student Assessment (PISA) yang di rilis oleh Organization for Economic Co-operation and Development (OECD) tahun 2019, Indonesia menempati rangking ke 62 dari 70 negara dalam hal literasi; salah satu penyebabnya adalah rendahnya budaya membaca masyarakat Indonesia. ${ }^{40}$

Temuan penelitan terkait dengan faktor penyebab rendahnya minat baca anak terhadap Alkitab di atas, penulis mengklasifikasinya ke dalam 4 faktor penyebab yakni:

(1) Lingkungan keluarga. Lingkungan keluarga mempunyai pengaruh yang besar terhadap

Sains, Humaniora dan Kebudayaan 13, no. 2 (December 12, 2020): 85-98.

40 Larasati Dyah Utami, “Tingkat Literasi Indonesia Di Dunia Rendah, Ranking 62 Dari 70 Negara," last modified 2021, accessed July 14, 2021, https:/ / perpustakaan.kemendagri.go.id/?p=4661. 
pembentukan kepribadian dan cara berpikir seseorang anak. Lingkungan yang baik terbentuk oleh iklim dimana orang-orang selalu memberikan dorongan positif dalam segala aspek kehidupan.

(2) Sarana dan fasilitas bacaan. Merujuk kepada ketersediaan dan keterjangkauan bahan bacaan Alkitab yang menarik, berkualitas dan beragam di rumah, taman bacaan terdekat, perpustakaan sekolah dan gereja.

(3) Teknologi. Anak-anak memiliki kecenderungan yang lebih tinggi untuk menikmati hiburan televisi dan bermain game di gadget.

(4) Literasi baca tulis. Rendahnya kemampuan anak dalam hal membaca, menghambat gairah atau motivasi anak untuk mencari, menemukan bahan bacaan dan membacanya. Gairah atau motivasi terhadap membaca merupakan salah satu indikator dari tinggirendahnya minat membaca.

(5) Pola asuh orang tua - merujuk kepada aspek keteladanan dan disiplin yang diterapkan orang tua di rumah. Kebiasaan orang tua membaca Alkitab adalah sebuah sikap dan perilaku yang akan dicontoh atau ditiru oleh anak. Begitu juga dalam hal kedisiplinan, orang tua wajib mengatur jadwal anak belajar, istirahat, bermain, dan tanggung jawab anak lainnya.

Argumentasi penulis di atas sejalan dengan teori atau hasil penelitian sebelumnya, bahwa ada beberapa faktor yang memengaruhi minat baca anak, di antaranya faktor lingkungan sosial, ${ }^{41}$ pola asuh orang tua dan perkembangan teknologi, ${ }^{42}$ serta lingkungan keluarga. ${ }^{43}$

Bertolak dari temuan penelitian di atas, sekaligus menjawab pertanyaan penelitian tentang upaya orang tua menumbuhkan minat anak terhadap Alkitab. Berikut ini, penulis menyarankan beberapa upaya dan strategi yang boleh ditempuh oleh orang tua.

(1) Memahami pentingnya Alkitab bagi orang Kristen. Jika orang tua memahami Alkitab adalah penting bagi kehidupan maka

${ }^{41}$ Rahim, Pengajaran Membaca Di Sekolah Dasar.

42 Rofiqul Khasanah, "Faktor-Faktor Yang Mempengaruhi Minat Membaca Siswa Kelas IVB SD Negeri Ngoto Sewon Bantul Tahun Ajaran 2014/2015" (Universitas Negeri Yogyakarta, 2015), https://eprints.uny.ac.id/27231/. tidaklah sulit membangun kebiasaan anak membaca Alkitab setiap hari.

(2) Menyediakan bahan bacaan Alkitab yang beragam di rumah, seperti Alkitab bergambar, cerita yang terdapat kuis atau permainan.

(3) Mengatur waktu ibadah dalam keluarga baik pada pagi hari maupun malam. Agar menyempatkan waktu untuk membaca Alkitab setidaknya 5-10 menit.

(4) Menggunakan media elektronik seperti gadget untuk keperluan membaca cerita Alkitab. Dengan cara mendowloand aplikasi seperti aplikasi Alkitab untuk Buku Cerita Anak Alkitab.

(5) Membatasi kegiatan anak seperti menonton $\mathrm{TV}$, bermain, menggunakan gadget, agar memiliki waktu untuk membaca Alkitab. Dengan cara mengatur schedule, anak tahu kapan ia berhenti melakukan aktivitas tersebut, sehingga kedisplinan anak untuk membaca Alkitab dapat teratur dengan baik.

(6) Jika anak kesulitan dalam memahami dan membaca Alkitab. Orang tua dapat meminta anak mulai membaca bagian singkat dalam Alkitab dan mengajukan tiga pertanyaan tentang apa yang diajarkan ayat/perikop tentang Tuhan? Apa yang diajarkan ayat/ perikop ini kepada anak tentang mengapa orang Krisen membutuhkan Juruselamat? Bagaimana ayat/perikop ini berlaku dalam hidup anak? Atau bagaimana hal itu dapat membantu anak untuk hidup sebagai seorang Kristen?

(7) Menjadikan waktu renungan sebagai kebiasaan. Hal ini dapat dilakukan dengan cara: (1) Membantu anak anak memahami apa yang dapat mereka peroleh dari memiliki waktu renungan yang teratur. (2) Saling share dengan anak-anak apa arti Firman Tuhan bagi orang tua dan bagaimana menghabiskan waktu bersama Tuhan dalam doa, yang dapat mengubah dan menghibur hidup orang tua; (3) Mencintai dan menghormati Firman Tuhan sendiri. Dengan terus menyediakan waktu untuk membaca atau

43 Tia Ulfa Amelia, "FAKTOR-FAKTOR YANG MEMPENGARUHI MINAT BACA SISWA SD NEGERI 125 PEKANBARU," Primary: Jurnal Pendidikan Guru Sekolah Dasar 9, no. 1 (February 12, 2020),

https:/ / primary.ejournal.unri.ac.id/index.php/JPFK $\mathrm{IP} /$ article/view/7565. 
mendiskusikan Kitab Suci bersama keluarga. Bahaslah ayat-ayat yang dibaca bersama untuk menerapkannya dalam kehidupan sehari-hari. Seiring bertambahnya usia anakanak, mereka harus belajar mengatur waktu mereka. Sama seperti ketika kita memulai kebiasaan sebagai orang dewasa, itu membutuhkan waktu, tetapi semakin banyak mereka berlatih, semakin mudah hasilnya.

(8) Orang tua dapat mendorong anak untuk berlatih membaca dengan suara yang keras. Hal ini membantu anak agar pelafalan yang mereka ucapkan tidak salah, dan seringseringlah memuji anak saat melakukannya. Tawarkan anak untuk membaca bagian isi Alkitab yang lain. Kemudian lakukan percakapan dan diskusi tentang apa yang dibaca dengan anak.

(9) Gereja dan pelayan pada waktu-waktu tertentu, perlu menjelaskan pentingnya membaca Alkitab melalui pemberitaan firman Tuhan (khotbah) dalam persekutuan jemaat di lingkungan pelayanan jemaat yang dihadiri oleh para orang tua dan anak-anak. Dan, yang utama adalah jemaat wajib mengaktifkan pelayanan Sekolah Minggu, mulai dari jemaat hingga ke seluruh lingkungan atau sektor pelayanan jemaat. Ini menjadi sarana bagi anak-anak untuk terlibat mendengar, membaca dan mempercakapkan Alkitab.

Secara umum, Alkitab adalah sumber dari segala kebenaran, inilah sebabnya mengapa tidak ada sumber selain Alkitab yang dapat mendidik seseorang untuk hidup dalam kebenaran dan memahami kehendak atau rencana Tuhan. Alkitab memiliki banyak petunjuk tentang bagaimana manusia harus hidup, dan ada banyak koreksi untuk menunjukkan kesalahan dan memperbaikinya. Prinsip-prinsip kehidupan yang dicatat dalam Alkitab memberikan sebagian besar disiplin yang dibutuhkan untuk berhasil mencapai tujuan.

Anak-anak usia sekolah dasar yang dalam teori generasi dikenal sebagai generasi Alpha 'mungkin' boleh dipahami sebagai generasi praKristen dan bukan sebaliknya. Mereka adalah sebuah kanvas kosong atau batu tulis bersih. Semakin jauhnya generasi $\mathrm{Z}$ dan generasi sebelumnya dari gereja memicu kekuatiran akankah sebagian besar Alpha tidak akan memiliki kerabat yang hidup yang pernah menghadiri gereja atau bahkan 'tahu' siapa Yesus? Pada akhirnya, orang tua memiliki kesempatan berpikir untuk kembali menginjil dan membagikan pesan Yesus kepada generasi pra-Kristen dengan cara yang sederhana dan murni.

Perkembangan kehidupan seorang anak merupakan tanggung jawab orang tua. Disinilah peran orang tua menjadi amat penting seperti tertulis dalam Ulangan 6:4-9: "Dengarlah, hai orang Israel: TUHAN itu Allah kita, TUHAN itu esa! Kasihilah TUHAN, Allahmu, dengan segenap hatimu dan dengan segenap jiwamu dan dengan segenap kekuatanmu. Apa yang kuperintahkan kepadamu pada hari ini haruslah engkau perhatikan, haruslah engkau mengajarkannya berulang ulang kepada anak-anakmu dan membicarakannya apabila engkau duduk di rumahmu, apabila engkau sedang dalam perjalanan, apabila engkau berbaring dan apabila engkau bangun. Haruslah juga engkau mengikatkannya sebagai tanda pada tanganmu dan haruslah itu menjadi lambang di dahimu, dan haruslah engkau menuliskannya pada tiang pintu rumahmu dan pada pintu gerbangmu".

Orang tua sebagai lembaga yang pertama dan utama dalam pendidikan anak harus mengenalkan Yesus kepada anak-anak sehingga mereka mengalami perjumpaan dengan Tuhan Yesus dalam keluarga. 2 Timotius 3:15-17 mengatakan "Ingatlah juga bahwa dari kecil engkau sudah mengenal Kitab Suci yang dapat memberi hikmat kepadamu dan menuntun engkau kepada keselamatan oleh iman kepada Yesus Kristus. Segala tulisan yang diilhamkan Allah memang bermanfaat untuk mengajar, untuk menyatakan kesalahan, untuk memperbaiki kelakuan dan untuk mendidik orang dalam kebenaran. Dengan demikian tiap-tiap manusia kepunyaan Allah diperlengkapi untuk setiap perbuatan baik".

Dengan demikian anak-anak harus dididik semasih ia muda sehingga apa yang telah ia terima dari kecil dapat diterapkan dalam kehidupan sehari-hari hingga ia besar nanti. "Didiklah orang muda menurut jalan yang patut baginya, maka pada masa tuanyapun ia tidak akan menyimpang dari pada jalan itu" (Amsal 22:6). Firman Allah memerintahkan hal ini kepada setiap orang tua supaya anak-anak yang mereka didik pada masa yang akan datang bahkan sampai pada masa tua mereka tidak menyimpang dari kebenaran firman Allah yang diajarkan. 


\section{KONKLUSI}

Menumbuhkan minat baca anak terhadap Alkitab harus disikapi sebagai bagian dalam upaya mendidik anak. Melalui upaya dan strategi yang tepat akan memberikan dampak kepada pemahaman anak khususnya anak usia 6-12 tahun agar dalam kesehariaanya juga dapat memaknai pentingnya membaca Alkitab.

Minimnya peran orang tua dalam menumbuhkan minat termasuk membiasakan anak membaca Alkitab, disebabkan oleh rendahnya pemahaman orang tua terhadap pentingnya membaca Alkitab bagi anak. Kesadaran orang tua yang masih rendah ini semakin diperburuk oleh ketiadaan aktivitas membaca Alkitab dalam ibadah keluarga di rumah, keteladanan dan pola asuh orang tua.

Selain buruknya budaya membaca masyarakat Indonesia secara umum, rendahnya minat baca anak terhadap Alkitab juga disebabkan oleh anak-anak lebih senang dan tertarik untuk membaca buku cerita bergambar (komik) dan materi atau buku pelajaran dari sekolah. Di sisi lain orang tua sering alpa dalam mendampingi anak-anak belajar termasuk membaca Alkitab, karena kesibukan orang tua dengan pekerjaannya serta keterbatasan kemampuan orang tua dalam mendidik anak sebagai akibat rendahnya pendidikan orang tua. Karena itu, orang tua perlu membimbing anak agar mau membaca Alkitab, dan menjadikan Alkitab sebagai pedoman dalam hidup; mengatur waktu agar anak mempunyai kesempatan untuk membaca Alkitab serta menerapkan upaya dan strategi yang dijelaskan di atas guna menumbuhkan minat dan membiasakan anak membaca Alkitab.

\section{REFERENSI}

Amelia, Tia Ulfa. "FAKTOR-FAKTOR YANG MEMPENGARUHI MINAT BACA SISWA SD NEGERI 125 PEKANBARU." Primary: Jurnal Pendidikan Guru Sekolah Dasar 9, no. 1 (February 12, 2020). https://primary.ejournal.unri.ac.id/index.ph $\mathrm{p} / \mathrm{JPFKIP} /$ article/view/7565.

Braun, Virginia, and Victoria Clarke. "Using Thematic Analysis in Psychology." Qualitative Research in Psychology 3, no. 2 (January 2006): 77-101.

http://www.tandfonline.com/doi/abs/10.1 191/1478088706qp063oa.

Darmadi. MEMBACA, YUUUK.....! "Strategi Menumbuhkan Minat Baca Pada Anak Sejak Usia Dini." Yogyakarta: Guepedia Publisher, 2018.

Darmawan, I Putu Ayub. "Pembelajaran Memorisasi Dalam Ulangan 6:6-9." EPIGRAPHE: Jurnal Teologi dan Pelayanan Kristiani 3, no. 1 (June 17, 2019): 21. http://www.stttorsina.ac.id/jurnal/index.ph $\mathrm{p} /$ epigraphe/article/view/50.

Datu, Marlianti. "Meningkatkan Minat Anak Sekolah Minggu Untuk Membaca Alkitab Di Era Globalisasi." OSF Preprints, 2020. https://osf.io/rfky9/.

Elisabeth. Pembelajaran PAK (Pendidikan Agama Kristen) Bagi Anak Usia Dini. Bandung: Bina Media Informasi, 2009.

Groome, Thomas H. Christian Religious Education. Jakarta: BPK Gunung Mulia, 2010.

Heriyanto, Heriyanto. "Thematic Analysis Sebagai Metode Menganalisa Data Untuk Penelitian Kualitatif." Anuva 2, no. 3 (November 22, 2018): https:// ejournal2.undip.ac.id/index.php/an uva/article/view/3679.

Khasanah, Rofiqul. "Faktor-Faktor Yang Mempengaruhi Minat Membaca Siswa Kelas IVB SD Negeri Ngoto Sewon Bantul Tahun Ajaran 2014/2015." Universitas Negeri Yogyakarta, 2015. https://eprints.uny.ac.id/27231/.

King, Philip J., and Lawrance E. Stager. Kehidupan Orang Israel Alkitabiah. Jakarta: BPK Gunung Mulia, 2012.

Koehler, Edward. Intisari Ajaran Kristen. Pematangsiantar: Kolportase Pusat, 2010.

Kristianto, Paulus Lilik. Prinsip Dan Praktik PAK. Yogyakarta: ANDI, 2006.

Lase, Delipiter, Amurisi Ndraha, and Gustav Gabriel Harefa. "Persepsi Orang tua Siswa Sekolah Dasar Di Kota Gunungsitoli Terhadap Kebijakan Pembelajaran Jarak Jauh Pada Masa Pandemi Covid-19." SUNDERMANN: Jurnal Ilmiah Teologi, Pendidikan, Sains, Humaniora dan Kebudayaan 13, no. 2 (December 12, 2020): 85-98.

Marbun, Purim. "Menggagas Pendidikan Karakter." Edukasi: Jurnal Pendidikan Agama Kristen 10, no. 1 (2019): 1-11. http://sttbi.ac.id/journal/index.php/edukas i/article/view/58.

Marshall, Catherine, and Gretchen B. Rossman. Designing Qualitative Research. 6th ed. Thousand Oaks, CA: SAGE Publications, Inc., 2015.

Moleong, Lexy J. Metodologi Penelitian Kualitatif. 
Bandung: Remaja Rosdakarya, 2017.

Nainupu, Astrid Maryam Yvonny, and Ayang Emiyati. "Kunci Keberhasilan Seorang Anak Dalam Pemaparan Alkitab." Didache: Journal of Christian Education 1, no. 2 (December 31, 2020): 91. https://journal.sttsimpson.ac.id/index.php/ DJCE/article/view/329.

Poerwadarminto, W. J. S. Kamus Umum Bahasa Indonesia. Jakarta: Balai Pustaka, 1984.

Purba, Asmat. “Tanggung Jawab Orang Tua Kristen Dalam Mendidikan Anak Menyikapi Pandemi Covid-19." EPIGRAPHE: Jurnal Teologi dan Pelayanan Kristiani 4, no. 1 (May 29, 2020).

http://jurnal.stttorsina.ac.id/index.php/epi graphe/article/view/151.

Rahim, Farida. Pengajaran Membaca Di Sekolah Dasar. Jakarta: Bumi Aksara, 2008.

Ratnasari, Yunita. "Pengaruh Pergaulan Teman Sebaya Terhadap Teman Sebaya Terhadap Minat Baca Siswa Kelas V SD Negeri Bojongsari I Kabupaten Purbalingga." Universitas Negeri Yogyakarta, 2011.

Richards, Lawrence O. Mengajarkan Alkitab Secara Kreatif. Bandung: Yayasan Kalam Hidup, 1994.

Russell, H Russell Bernard and Bernard H. Research Methods in Anthropology: Qualitative and Quantitative Approaches. Walnut Creek: AltaMira Press, 2006.

Sidjabat, B. S. Membangun Pribadi Unggul. Yogyakarta: Andi Offset, 2011.

Sidjabat, B. Samuel. Strategi Pendidikan Kristen Suatu Tinjauan Teologis-Filosofis. Yogyakarta: Andi Offset, 1994.

Smit, Brigitte, and Anthony J. Onwuegbuzie. "Observations in Qualitative Inquiry: When What You See Is Not What You See." International Journal of Qualitative Methods 17, no. 1 (December 1, 2018): 160940691881676. http://journals.sagepub.com/doi/10.1177/1 609406918816766.

Stanislaus, Surip. Bimbing Anak Cinta Alkitab. Yogyakarta: Kanisius, 2010.

Tjen, Anwar, trans. Katekhismus Dr. Martin Luther. 5th ed. Jakarta: BPK Gunung Mulia, 2007.

Utami, Larasati Dyah. "Tingkat Literasi Indonesia Di Dunia Rendah, Ranking 62 Dari 70 Negara." Last modified 2021. Accessed July 14 ,

2021. https:// perpustakaan.kemendagri.go.id/?p= 4661.

Wau, Hasanema. Gereja Pasca Covid-19. Yogyakarta: Andi Offset, 2020.

Wijayani, Elisabeth Lita. "Efektivitas Penggunaan
Cerita Bergambar Sebagai Media Pengenalan Tokoh Kitab Suci Pada Siswa Kelas II Sekolah Dasar Soegijapranata Klaten Utara." Universitas Sanata Darma, 2017.

Undang-Undang Nomor 23 Tahun 2002 Tentang Perlidungan Anak. Jakarta: Sekretariat Negara Republik Indonesia, 2002.

Undang-Undang Republik Indonesia Nomor 20 Tahun 2003 Tentang Sistem Pendidikan Nasional. Sekretariat Negara Republik Indonesia, 2003.

Undang-Undang Republik Indonesia Nomor 35 Tahun 2014 Tentang Perlindungan Anak. Sekretariat Negara Republik Indonesia, 2014. 